\title{
Revitalization of Social Studies Education: A Developmental Study Based on Dick and Carey Instructional Design
}

\author{
$1^{\text {st }}$ Muhammad Khoiron \\ Universitas Negeri Surabaya \\ Surabaya, Indonesia \\ muhammad.khoiron.ips@gmail.com
}

\author{
$2^{\text {nd }}$ Neni Wahyuningtyas \\ Universitas Negeri Malang \\ Malang, Indonesia \\ neni.wahyuningtyas.fis@um.ac.id
}

\author{
$3^{\text {rd }}$ Miftakhuddin \\ Universitas Negeri Yogyakarta \\ Yogyakarta, Indonesia \\ tuplick110@gmail.com
}

\begin{abstract}
The format of community behavior in the 4.0 industrial revolution shows a distinctive transformation. Accordingly, this study aims to find out ways to develop social studies learning, so that social studies learning can conform to the trends of those changes, especially in the developing of attitudes and skills dimensions. This study used a literature review method, which was applied to Dick and Carey's instructional development design. The research subjects were academic works in educational scope and the related studies published in reputable international journals. The collected data was analyzed using content analysis techniques. The results of the study show that the revitalization of social studies teaching can be done by focusing on three domains. First, the formulation of goals (what competencies you want to build on your pupils). Second, the organization of teaching materials (what are the materials and how pupils can achieve these competencies). Third, evaluation techniques (how to know that the competencies have been achieved). The implications of these results confirm that social studies learning should be contextual (based on sociocultural environment), factual (based on reality), and actual (based on current issues)
\end{abstract}

Keywords: Dick and Carey instructional design, learning development, revitalization of social studies

\section{INTRODUCTION}

Nowadays, education in schools is being criticized more concerned with cognitive aspects than affective aspects [1]. In practice, there are still many teachers who do not consider the affective aspects because the domain is highlighted in learning only. Especially for social studies subject, there are still many teachers who teach by giving memorizing material, instead of understanding material [2]. Even more, teachers present learning material without being followed by discussion or reflection with their pupils [3]. As a result, learning material obtained from schools is not used by pupils in interacting with their environment. This happens because the pupils only learn about something that has been stated as truth solely according to social science [4]. In short, such learning models do not provide access for pupils to jointly examine and critically review learning material, so that meaningfulness is not obtained by pupils, let alone its usefulness.

Seeing these conditions is indeed quite alarming because social studies are not supposed to be taught by the "indoctrination method". The social studies learning process is essential not only focused on material that develops cognitive abilities but also must develop the character [5]. Competencies that must be possessed by pupils after studying social studies are the ability to live in a society, the ability to identify and solve problems, develop social care attitude, use of critical thinking and curiosity, the ability to adapt to technological advancements, and raising the nationalism [4]. Thus it can be understood that the results of social studies learning should not be limited to cognitive aspects (knowledge). He must be able to cover aspects of skills and attitudes; social skills and attitudes based on positive characters.

Therefore, the question that currently needs to be answered is: how do actions need to be taken to create social studies learning that does not only focus on cognitive dimensions? This principle needs to be considered because social studies learning with a balanced portion will develop the character of pupils, which is, in turn, will play the role as the basis for pupils when they blend in with the wider community. This is mainly because of inevitably the trend of social studies learning will encounter a variety of social realities, including the 4.0 industrial revolution that makes people turn to integration and digital solutions [6], [7]. Based on this urgency, it is important to revitalize social studies education, especially through studies on its development.

This study used Dick and Carey's development approach as a basis for thinking and flow so that the development process took place systematically. The choice of this model was based on two considerations, namely: Dick and Carey's development model has a coherent and clear system approach [8]; this approach is observant in paying attention to the components of learning such as teachers, pupils, materials, learning processes, 


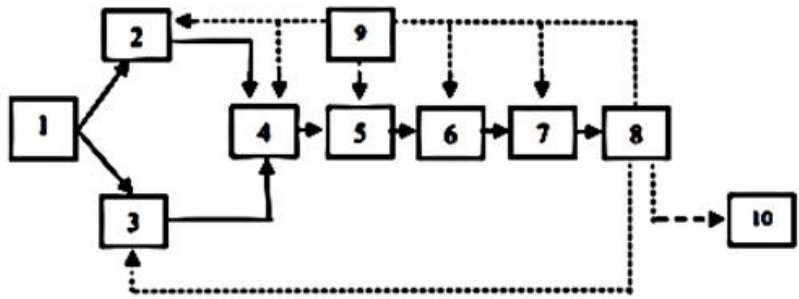

learning strategies, learning environments, and learning outcomes [9].

Methodically, this study was conducted through a review of academic works, to establish a reliable base for recommendation to school and teacher. Guided by the research question, the following inclusion criteria were applied to obtain the papers: 1) papers should be based empirical research; 2) papers must be published in a peer-reviewed journal, and 3) papers must clearly describe how social studies is taught. To ensure that the review ran correctly, we carried out the following steps:

1.Scoping review: we developed criteria for specifying which studies would be included in the review.

2.Searching for studies: each member of the research team set out to identify relevant studies

3.Screening studies: each piece of literature was screened against the inclusion criteria.

4.Describing and mapping: we outlined the methods and finding from each included study.

5.Synthesizing study findings: we were looking for pathways to bring the results of the mapping to provide an accessible combination of results from individual studies in structured summaries.

6.Concluding: we drew up a set of recommendations closely linked to the findings of the synthesis.

\section{METHOD}

Compared to the other design of learning developments, Dick and Carey's design has two advantages. First, it is more suitable for use in the educational context, especially in the classroom teaching practices [10]. The statement is based on the stages of development that allow the development of teaching materials, both in the form of verbal information, intellectual skills, or in the field of motor skills and psychic behavior [11]. Second, the design of the development of Dick and Carey belongs to the system approach model [12], [13]. This means that the approach used during development is not only sufficiently based on theory and results of studies, but also takes into account practical experience [14]. The steps in the design of the approach include; 1) Identify Instructional Goals; 2) Conduct Instructional Analysis; 3) Analyze Learners and Contexts; 4) Write Performance Objectives; 5) Develop Assessment Instrument; 6) Develop Instructional Strategy; 7) Develop and Select Instructional Materials; 8) Design and Conduct Formative Evaluation of Instruction; 9) Revise Instruction; 10) Design and Conduct Summative Evaluation [15]. More simply can be considered in Figure 1.
Fig. 1. Systematic Design of Instruction of Dick and Carey

Basically, there are indeed ten steps that must be done when the teacher uses the Dick and Carey instructional design. Referring to these development steps, this study seeks to find findings that focus on: 1) general learning objectives; 2) Results of instructional analysis; 3) The context and conditions of the learner; 4) Competency standards; 5) Assessment Instruments; 6) Learning Strategies; 7) Teaching materials; and 8 ) Formative and summative evaluation format in social studies learning.

\section{RESULTS AND DISCUSSION}

\section{9) Identify Instructional Goals}

Dick and Carey's instructional design positions identification of general goals as the basis for the next phase, so it is important to set general goals that are in line with social studies goals. According to the National Council for Social Studies (NCSS), social studies aim to prepare pupils to face various life dilemmas, speculate, think critically, and make personal and joint decisions based on various perspectives in state life and democracy [16]. In addition, based on the constitution of Indonesian Minister of Education and Culture number 20 of 2016 concerning competency standards for primary and secondary education graduates, the attitudes dimensions of graduates of social studies must have behaviors that reflect: 1) faith and piety to God; 2) good personality, honest and caring; 3) responsible; 4) true lifelong learners; and 5) physically and mentally healthy in accordance with the development of children in the family, school, community and surrounding natural environment, nation, country and regional region [17].

While based on the constitution of Indonesian Minister of Education and Culture number 35 of 2018 concerning Curriculum 2013, the aim of social studies education at the junior high school level is to emphasize understanding of the nation, spirit, nationalism, patriotism, and community activities in the economy in space or territory of the Republic of Indonesia [18]. If we pay attention to the current conditions and correct them with the aim of social studies education contained in the NCSS and the regulation of the Indonesian Minister of Education and Culture, we can understand that the focus of learning in social studies education is indeed not only 
in the knowledge dimension. Social studies education is also responsible for development in the realm of attitudes and skills. Therefore, we formulate a general goal of social studies learning as "The formation of human characters who can live side by side in a society in the mindset of dynamic times, critical in thinking, have social care, can analyze and solve problems around them, and have a good nationalism".

\section{B. Conduct Instructional Analysis}

After the stage of determining the general goal of learning has been completed, the next step is to determine the subskill needed to achieve general goals, both covering the dimensions of knowledge, attitudes, and skills [15]. The three components of the subskill must be arranged based on general objectives so that there is no misconception. In the knowledge dimension of the subskill component, we compose based on the present conditions contained in the NCSS and the regulation of the Indonesian Minister of Education and Culture number 20 of 2016.

Referring to the purpose of social studies according to the NCSS and the education ministerial unit above, we formulate the results of the learning analysis as follows. Some aspects that must be developed in the knowledge dimension include: having factual, conceptual, procedural, and metacognitive knowledge at a simple technical and specific level concerning 1) science, 2) technology, 3) art, and 4) culture [17]. Whereas in the dimensions of skills, they include: having thinking and acting skills: 1) creative, 2) productive, 3) critical, 4) independent, 5) collaborative and 6) communicative. Then on the dimensions of attitude; Having behavior that reflects attitudes; 1) faithful and fearful of God Almighty, 2) character, honest and caring, 3) responsible, 4) true learners throughout life, and 5) physically and mentally healthy in accordance with the development of children in the family, school, community, and environment natural environment, nation, country and regional region [17].

\section{Analyze Learners and Context}

Analyzing pupils and the current context is needed because it is part of the previous parallel analysis phase. This stage is based on the principle that the teacher must know the condition of his pupils, know what they are learning in what kind of context, and the material to be conveyed will be used in what kind of environment. Analysis at this stage will be very helpful in considering the choice of model or learning strategy used [15]. Even by knowing the characteristics of pupils and their context, the teacher can be helped in determining learning resources. This is the supplementary advantage of this stage, which is to change the school habits that generally use the teacher as a source of learning (teachercentered) [19], to use the teacher as a facilitator (studentcentered). Through pupil analysis and context, the learning that occurs will become more contextual and based on pupils' empirical experience.

Education in schools, including social studies, must indeed be able to keep up with the development of the pupils' world wherever they are. If there is a development in the world of technology, for example, we must also be able to follow and adapt to technological developments. Director General of Education, Singapore Ministry of Education, Ho Peng, once said: "... If we want to get student attention, then we must understand technology. If not, we will lose pupils in school" [20]. Therefore, in social studies learning it is very important to pay attention to the current situation of pupils, both in terms of science, technology, art, and culture.

For example, a country that pays attention to current conditions and the world of pupils in Singapore. The country occupies the number one position in the world of education for the Programme for International Student Assessment (PISA) [21]. Education in Singapore understands the importance of understanding the world of pupils and their current conditions. Learning that occurs there, ultimately becomes fun and more meaningful. The running process can stimulate pupils to be enthusiastic and active in participating in their learning [20].

\section{Write Performance Objectives}

The formulation of performance goals must be specific about what abilities pupils will get when finished through the learning process [15]. Based on the Indonesian Minister of Education and Culture regulation number 37 of 2018 concerning core competencies and basic competencies, the competency standards for social studies learning at the elementary and secondary education levels are divided into three different dimensions, namely: knowledge, attitudes, and skills [22].

It is written on the core competency of grade 9, stated that the formulation of the competency of spiritual attitudes is "respecting and living the teachings of the religion that is followed". The formulation of the competency of social attitudes is "showing honest behavior, discipline, responsibility, caring (tolerance, cooperation), courtesy, and confidence in interacting effectively with the social and natural environment within the scope of association and its existence". Both of these competencies were achieved through indirect learning and teaching, namely through exemplary, habituation, and school culture, taking into account the characteristics of the subjects and the needs and conditions of pupils [22].

Connected with attitude competence, the dimension of knowledge is understanding and applying knowledge (factual, conceptual, and procedural) based on curiosity about science, technology, art, and culture related to phenomena and events that appear to the eye. Then in the dimensions of skill, there are processing, presenting, and reasoning in the concrete realm 
(using, parsing, stringing, modifying, and creating) and abstract realms (writing, reading, counting, drawing, and compose) in accordance with what is learned in schools and other sources are the same in viewpoints/theories [22].

It can be seen from the competencies written in the regulation of the Indonesian Minister of Education and Culture number 37 of 2018 that it is quite clear. In social studies learning, the goal of the performance is not limited to the dimensions of knowledge. But performance goals must also pay attention to the domain of attitudes and skills. For example, such as honest behavior, and responsible and skilled in the use of technology.

\section{E. Develop Assessment Instruments}

Based on general objectives and performance, assessment instruments can be prepared [15]. Thus, it will be known how far the progress has been achieved from the ongoing learning. Because the assessment is an evaluation of student learning processes that do not override learning outcomes [23].

Considering the dimensions of social studies include knowledge, skills, and attitudes, the instruments arranged must also be able to accommodate these three dimensions. Alternative assessment instruments that can be used so that all aspects are represented include using 1) Performance-based evaluation, 2) Portfolio, 3) Project-based evaluation, 4) Rubrics, 5) Checklists, 6) Concept maps, 7) Rating scales, 8 ) Observation forms, 9) Oral presentations, 10) Attitude scales, 11) Self-evaluations, 12) Peer evaluations, 13) Group evaluations, 14) Interviews, 15) Constructed grids, 16) Diagnostic trees, and 17) Word association tests [24].

Social studies teachers can develop assessment instruments from the various alternatives above. For example, it is not limited to the paper-based test but can also use interviews, attitude assessment, self-assessment or presentation of the results. The development of such instruments needs to be carried out according to the situation, context, and characteristics of pupils. If necessary, the teacher may hold a practical exam for social studies, moreover, there has never been a practical examination for social studies subjects at school. So far, practical exams have occurred in the subjects of religious education and character, Indonesian language, English, cultural arts, physical education, craft and entrepreneurship, and regional languages [25]. Whereas to assess the skills and attitudes of social studies competencies that are mastered by pupils, it is not enough to be measured through the paper-based test. So in this case, what must be developed in the process of assessing social studies is on the part of the assessment of attitudes and skills along with their assessment instruments. However, the assessment instrument should be tested for validity and reliability before it is used to assess student performance and competency achievement.

\section{F. Develop an Instructional Strategy}

By having the previous five steps, a teacher can develop learning strategies that can support learning achievement, based on the theory of learning and the results of recent research [15]. Learning strategies will affect the learning process in the classroom. Therefore it is important to determine learning strategies based on logical and academic considerations. If seen, based on the applicable curriculum and current conditions, then one of the learning strategies that can be developed in social studies is STEAM learning strategy (Science, Technology, Engineering, Art, Mathematics). Teachers can adopt STEAM learning and use it to be developed following social studies learning needs.

STEAM learning strategy is one of the breakthroughs in the world of Indonesian education to invite pupils to think critically and have techniques or designs to solve problems based on their mathematics and science skills. STEAM's strategy is to answer the challenges of the 21 st century that require people who have technological skills, information management, innovation, learning, career, and global awareness and character [26].

In general, STEAM learning is a strategy whose superiority is to help achieve social studies learning objectives in schools more effectively. The intended purpose is what we discussed above, as well as the previous five steps. All these objectives can be accommodated with STEAM learning strategies. Because of this, the strategy is one of the strategies that social studies teachers must consider in choosing their learning strategies.

\section{G. Develop and Select Instructional Materials}

The minimum teaching material used in social studies learning is the latest following the current conditions of pupils because basically, the steps in developing and choosing learning materials are very dependent on the results of what you want to achieve in learning and the availability of resources [15]. By understanding the first to the sixth step, it will be easier in the selection of learning materials. Because before choosing teaching materials we must pay attention to; general learning objectives, conditions, and context of pupils, goals of learning performance, strategies, and assessment instruments.

To synchronize with the current development and conditions of pupils, the selection and development of learning materials can use the theme "social media in social life", for example. This material can be one of the right choices because currently social media is embedded in our lives. In America, $62 \%$ of people use social media as a platform for getting news [27]. While in Indonesia, research from the Indonesian Internet Service Providers Association shows that $87 \%$ use the internet 
for social media purposes [28]. Accordingly, the theme of social media will be a contextual part of student learning.

\section{H. Design and Conduct a Formative Evaluation}

Conducting an assessment is an important part of learning, one of the assessments that can be done is to do a formative evaluation. Evaluation that aims to improve the learning process that occurs [15]. Or it could also be said that formative evaluation is a test conducted at the end of each lesson which intends to determine the extent to which participants master competency after following the learning process [29]. Hence the assessment of social studies learning must pay attention to three aspects that have been mentioned before (i.e knowledge, attitudes, and skills).

As discussed in the section on compiling assessment instruments. What happens in Indonesian schools is generally less attention to the dimensions of attitudes and skills. This is much reflected in the learning process and its assessment. Therefore, so that social studies can be revitalized, the assessment must also pay attention to all dimensions. For example, by evaluating skills and attitudes after the learning process has finished through the results of observations. Style of assessment that can be implemented including 1) attitude assessment by paying attention to attitude changes in pupils after each lesson. Both in terms of words and actions of pupils can be reflected; 2) assessment of skills can be measured by observing whether there is a change in pupils in critical thinking or collaborating by paying attention to their abilities when working together or expressing their opinions.

\section{Revise Instruction}

The next step in the design and development process is to revise. Data that has been collected from the formative evaluation is used to identify difficulties experienced by pupils in achieving goals and to link these difficulties with specific deficiencies in instruction. The dashed line in Figure 1. (Instruction Revision) shows that data from the formative evaluation are not only used to revise the instruction itself but are used to re-examine the validity of the learning analysis [15]. Thus, social studies learning developed can be truly based on existing data and needs.

\section{J. Design and Conduct a Summative Evaluation}

Although summative evaluation is the peak evaluation of the learning process, this is not part of the design process. Structurally, the summative evaluation was carried out in the outside of the systematic stages of the designs of Dick and Carey [15]. In general, summative evaluation can be referred to as a test that is used to obtain data from the results of the learning process after it has been carried out in a series of programs, such as Final Semester Examination [29].
As already discussed in the assessment instrument section. For the learning process at social studies, it is necessary to hold an assessment that leads to the dimensions of attitudes and skills. Therefore, the summative evaluation does not only focus on the paper-based test but must also include a practice test. Thus the dimensions of attitudes and skills can be measured more authentically.

\section{CONCLUSION}

Leastwise, there are two main problems in social studies learning, namely the problem of contextuality and the problem of the development of unbalanced competencies. Contextuality problems arise because the delivery of material is very fixated on books (textbooks), not referring to the environment around pupils. While the problem of the focus of competency development arises because teaching orientation is more focused on the ability to remember and understand the material (cognitive), not evenly at the level of implementing material as learning outcomes (attitudes and skills).

Based on data analysis in the discussion above, theoretically, these problems can be overcome well through the application of learning development that refers to the design of Dick and Carey. The design is said to be a solution because the signs in each stage do not tell the teacher what to do, but how and why something should be done. Practically, when the teacher runs the guidelines consistently and obediently, social studies learning will run more contextually and be able to develop cognitive, affective, and psychomotor abilities.

Theoretically, when the three domains have developed in a balanced manner, the formation and development of the characters mentioned by the NCSS and the minister of education and culture above will occur automatically. Therefore, the development of learning that refers to the design of Dick and Carey emphasizes the stages that play a significant role, namely the phase of formulation of objectives, the preparation phase of the material and the selection of learning strategies, and the evaluation phase. The objective formulation phase is to determine what competencies are to be achieved through social studies learning, the material preparation phase and the selection of strategies on what is given so that competencies are achieved and how to provide them, while the evaluation phase is responsible for measuring how far pupils can achieve competencies or learning objectives formulated at the beginning just now.

As an implication, this research increasingly confirms that the main purpose of social studies is to create a society that is not only intellectually intelligent but also socially intelligent. Therefore social studies teaching, as reviewed above, must be contextual (according to conditions in the surrounding environment), factual (according to facts), and actual (following the latest events and developments). 


\section{REFERENCES}

[1] M. Edy Surahman, "Peran Guru IPS Sebagai Pendidik Dan Pengajar dalam Meningkatkan Sikap Sosial Dan Tanggung Jawab Sosial Siswa SMP," Harmon. Sos. J. Pendidik. IPS, vol. 4, no. 1, pp. 1-13, 2017.

[2] I. L. Florentina Jenanu, Arifin Maksum, "Peningkatan Hasil Belajar IPS dengan Menggunakan Metode Pembelajaran Talking Stik untuk Sekolah Dasar," Perspekt. Ilmu Pendidik., vol. 28, no. 2, pp. 108-113, 2014.

[3] S. BURSA and A. F. ERSOY, "Social Studies Teachers' Perceptions and Experiences of Social Justice," Eurasian J. Educ. Res., vol. 16, no. 64, pp. $1-35,2016$

[4] S. H. Hasan, "Revitalisasi Pendidikan IPS dan Ilmu Sosial untuk Pembangunan Bangsa," vol. 1, no. November, pp. 1-17, 2007.

[5] Sardiman A.M, "Revitalisasi peran pembelajaran ips dalam pembentukan karakter bangsa," Cakrawala Pendidik., vol. Edisi Khus, pp. 147-160, 2010.

[6] P. K. Muhuri, A. K. Shukla, and A. Abraham, "Industry 4.0: A bibliometric analysis and detailed overview," Eng. Appl. Artif. Intell., vol. 78, no. November 2017, pp. 218-235, 2019.

[7] A. G. Frank, L. S. Dalenogare, and N. F. Ayala, "Industry 4.0 technologies: Implementation patterns in manufacturing companies," Int. J. Prod. Econ., vol. 210, pp. 15-26, 2019.

[8] W. N. Aji, "Model Pembelajaran Dick and Carrey Dalam Pembelajaran Bahasa Dan Sastra Indonesia," Kaji. Linguist. dan Sastra, vol. 1, no. 2, p. $119,2017$.

[9] T. D. Angelo, J. C. Bunch, and A. Thoron, "Instructional Design Using the Dick and Carey Systems," IFAS Ext. Univ. Florida, pp. 1-5, 2018.

[10] H. Bello and U. O. Aliyu, "Effect of Dick and Carey Instructional Model on The Performance of Electrical/ Electronics Technology Education Pupils in Some Selected Concepts in Technical Colleges of Northern Nigeria," Int. Res. Journals, vol. 3, no. March, pp. 277-283, 2012.

[11] F. A. Nai, I. N. S. Degeng, P. Setyosari, and U. Widiati, "Teaching Material Development of Learning and Teaching Course Through Lesson Study Application for University Pupils," Educ. 21th Century Responding to Curr. Issues, pp. 273-283, 2016.

[12] A. Sharif and S. Cho, "21st-Century Instructional Designers: Bridging the Perceptual Gaps between Identity, Practice, Impact and Professional Development," RUSC. Univ. Knowl. Soc. J., vol. 12, no. 3, p. 72, 2015.

[13] C. Obizoba, "Instructional design models - Framework for innovative teaching and learning methodologies," Int. J. High. Educ. Manag., vol. 2, no. 1, pp. 40-51, 2015.

[14] A. A. Ibrahim, "Comparative Analysis between System Approach, Kemp, Journal,” Int. J. Educ. Res., vol. 3, no. 12, pp. 261-270, 2015.
[15] J. O. C. Walter Dick, Lou Carey, The Systematic Design of Instruction, Eighth Edi. New Jersey: Pearson Education, 2015.

[16] NCSS, "NCSS Position Statement A Vision of Powerful Teaching and Learning in the Social Studies," Soc. Educ., vol. 80, no. 3, pp. 180$182,2016$.

[17] Kementerian Pendidikan dan Kebudayaan, Peraturan Menteri Pendidikan Dan Kebudayaan Nomor 20 Tahun 2016 Tentang Standar Kompetensi Lulusan Pendidikan Dasar Dan Menengah. Indonesia, 2016, pp. 1-8.

[18 ]Kemendikbud, Perubahan Atas Peraturan Menteri Pendidikan Dan Kebudayaan Nomor 58 Tahun 2014 Tentang Kurikulum 2013 Sekolah Menengah Pertama/Madrasah Tsanawiyah. Indonesia: Kementerian Pendidikan dan Kebudayaan, 2018, pp. 1-10.

[19] S. Rabiatun Adwiah, Punaji Setyosari, "Pengembangan E-Module Ips Dengan Pendekatan Kontekstual Untuk Siswa Kelas Vii Smpk Mater Dei Probolinggo," J. Pendidik. Teor. Penelitian, dan Pengemb., vol. 1, no. 9, pp. 1797-1805, 2016.

[20] Edutopia, Singapore's 21st-Century Teaching Strategies (Education Everywhere Series). Singapore: Edutopia, 2012.

[21] OECD, "Pisa 2015 Results in Focus," Paris, 2015.

[22] Kementerian Pendidikan dan Kebudayaan, Peraturan Menteri Pendidikan Dan Kebudayaan Republik Indonesia Nomor 37 Tahun 2018.Tentang Perubahan Atas Peraturan Menteri Pendidikan Dan Kebudayaan Nomor 24 Tahun 2016 Tentang Kompetensi Inti Dan Kompetensi Dasar Pelajaran Pada Kurikulum 2013 Pada Pendi. Indonesia, 2018.

[23] Ana Ratna Wulan, "Pengertian Dan Esensi Konsep Evaluasi, Asesmen, Tes, Dan Pengukuran," pp. 1-12, 2016.

[24] B. TAY, "Alternative Assessment Methods in Social Studies Associate," NEW APPROACHES Soc. Stud. Educ., vol. 2, no. 1, pp. 13-30, 2017.

[25] SMPN Negeri 1 Gresik, "Program Ujian Praktik Siswa Kelas IX SMS Negeri 1 Gresik Tahun Pelajaran 2015 - 2016." SMP Negeri 1 Gresik, Gresik, Indonesia, 2016.

[26] A. D. Wijaya, K. Dina, and Amalia, "Implementasi Pembelajaran Berbasis STEAM (Science, Technology, Engineering, Art, Mathematics) Pada Kurikulum Indonesia," Semin. Nas. Fis. dan Apl., no. November, pp. 85-88, 2015.

[27] E. Shearer and J. Gottfried, "News Use Across Social Media Platforms 2017 | Pew Research Center." p. 16, 2017.

[28] Asosiasi Penyelenggara Jasa Internet Iindonesia, "Penetrasi \& Perilaku Pengguna Internet Indonesia 2017," KOMINFO. pp. 1-39, 2017.

[29] S. F. Selegi, "Model Evaluasi Formatif-Sumatif Terhadap Motivasi Belajar Mahasiswa Pada Mata Kuliah Perencanaan Pengajaran Geografi," no. November, 2017. 